\title{
Tax Amnesty Policy on Good Governance Principle in Indonesia
}

\author{
Noni Nurameliani ${ }^{1}$, Abdul Rahman ${ }^{2}$ \\ Politeknik STIA LAN Bandung, Jl. Cimandiri 34-38 Bandung 40115 ${ }^{12}$
}

\{abdul.rahman@poltek.stialanbandung.ac.id²\}

\begin{abstract}
This Article is intended to examine the government's policy on tax amnesty. The existence of a tax amnesty is an idea owned by the government to transfer the assets of its domestic taxpayers (Repatriation) and declare assets without multiplication into the country. Tax amnesty is one of the prominent issues in public administration where the government implements changes in the social order towards a more positive direction, so that the ideals of a democratic state can be implemented in accordance with the 1945 Constitution of the Republic of Indonesia. tax amnesty on the principle of good governance. This study uses a qualitative approach with a descriptive method. Data collection is done through literature study. The purpose of research is to obtain information and describe the empirical reality behind the phenomenon in depth, detail, and thoroughness so that research results emphasize meaning rather than generalizations. The results of this study indicate that the principle of good governance echoed by the government by imposing a tax amnesty policy is proven to be able to increase public awareness of taxpayers. Therefore, a more comprehensive improvement through the involvement of various agents to respond to the development of public enthusiasm in paying taxes.
\end{abstract}

Keywords: Tax Amnesty, Good Governance, Repratriation

\section{Introduction}

Taxes are one of the sources of income for the state to develop and feed the country's economy. Taxes are not only one of the state's revenues, but also evidence of the community's contribution to the state. In addition, taxes are another variable used by the state as a symbol of "Gotong Royong" for the benefit of the nation and the state. As explained by Agung [1] quoted by Rahimun [2], a tax is a collection that the state receives to improve people's lives. In his life, the municipality does not always immediately observe the fulfillment of its tax obligations by the municipality; in its continuity, the payment of taxes does not always go smoothly, but tends to lead to losses. Recalling the widespread negligence of the population in paying taxes or the inability of the population to pay their high tax debts directly, the Indonesian government announced a tax amnesty in 2016.

The latest innovation, namely the tax amnesty policy in Indonesia, is due to the worsening economic situation. The existence of a tax amnesty is the idea of the state to transfer the assets of its domestic taxpayers (repatriation) and declare assets without increasing in the country [3]. Meanwhile, Law No. 11 of 2016 on Tax Amnesty states that a tax amnesty is the abolition of taxes that must be owed but not subject to tax administration and criminal tax sanctions through asset disclosure and ransom payments. A tax amnesty, or tax amnesty, is a tax program 
provided to debtors, including the elimination of taxes, the removal of tax administration sanctions, and the abolition of criminal penalties in the area of taxation of assets acquired and not listed in the SPT. by paying the tax debt and paying the ransom [4].

According to Justyari [3] and Ispriarso [4], Indonesia is introducing a tax amnesty for three reasons, namely:

a. The number of assets of Indonesians that are not reported domestically on the annual tax return because the circulating economy is a black or illegal economy.

b. The existence of a state company to collect mandatory contributions from the population, the size of which is not small, for the growth and growth of the country's economy, as well as the public's awareness of the need to pay taxes.

c. Potential income from entrepreneurs or debtors who pay less taxes but do not report them lead to penalties related to tax evasion [5].

According to Yustiari [3], a far-reaching tax amnesty policy can be beneficial to the government in supporting the macroeconomics and raising awareness of taxpayers' tax debt so that principles of good governance will emerge and be created for them. Local community. Tax amnesty is one of the most important issues of public administration, when the government implements changes in the social order in a more positive direction so that the ideals of a democratic state can be realized in accordance with the constitution of the Republic of Indonesia since 1945 a form of proof of community control in the state in the form of good governance [6].

The government's policy on the implementation of the tax amnesty program is one of the administrative processes carried out by the government in relation to the country's economy through the use of human resources so that the interests of the people can be realized on the principles of fairness and equality., equity, efficiency, transparency and accountability [6], [7]. In 1997, Safrijal mentions the principles of good governance within UNDP, namely: Participation, legal certainty, transparency, accountability, consistency, fairness, efficiency and effectiveness, accountability and strategic vision.

One of the principles laid down in the tax amnesty program is the principle of responsibility and participation. Participation is a form of public interest aimed at raising awareness of how taxes are paid through this program, while accountability is a principle of the state helping people to raise awareness and help so that people can pay their taxes by counting.

\section{Literature Review}

\subsection{Tax amnesty}

A tax amnesty is a way for taxpayers who are in arrears with a specified amount of tax for a limited time and in the form of an amnesty for tax debts, both in terms of interest and fines related to the tax, for a limited period of time previous tax period or for a specified period without paying tax. are prosecuted [2]. Slegman [8] describes that a tax amnesty is the abolition of taxes due, the abolition of tax administration sanctions, the abolition of criminal tax penalties and the abolition of some criminal penalties related to ransom.

Meanwhile, Law No. 11 of 2016 on Tax Amnesty clarifies that a tax amnesty is the elimination of taxes that must be owed but not associated with tax administration penalties and criminal penalties for taxes for property disclosure and ransom payments. A tax amnesty, or tax amnesty, is a tax program granted to debtors, including the abolition of taxes, the lifting of 
tax administration sanctions, and the lifting of criminal penalties in the area of taxation of assets that are acquired and not presented in the SPT by removing any tax arrears settle and pay the ransom [4].

\subsection{Principles of good governance}

Good governance is the quality of the relationship between government and the people it serves and protects [9]. According to the World Bank [10], good governance is the way in which the government contributes to the development of society with its authority to manage human, social and economic resources [11]. UNDP (One National Development Planning) also mentions that a good governance program is the practice of exercising administrative authority across departments [6]. According to Wiriaatmadja [12], good governance is a broad coverage of aspects of life from legal, political, economic and social aspects that are closely related to the main tasks of government administration, both executive, legislative and judicial.

The existence of the process of overcoming the crisis is to create a government with principles of good governance in which the crisis will stimulate a comprehensive reverse flow process that will improve the state economy and public administration through the application of the principles of the Good requires administration [13]. According to Sugiarty [14] in his study, good governance is the implementation of solid and responsible development governance that follows democratic principles, with an efficient market in order to avoid misallocation of investment funds and to prevent both political and administrative corruption in budget implementation. Discipline and create a legal and policy framework for business growth.

\section{Research Method}

This study uses a qualitative approach with a descriptive method. The purpose of the study is to obtain information and describe in detail, in detail and thoroughly the empirical reality of this phenomenon, so that the results of the study emphasize the importance, rather than generalization [15]. Hence, the qualitative methodology generates descriptive data in the form of written or spoken words from the form of policy measures [16]. According to Moleong [17], qualitative research is research that aims to understand what phenomena the research subjects experience, such as behavior, perception, motivation, and action. This study examines how tax amnesty policies relate to good governance.

\section{Result and Discussion}

Indonesia is essentially a democratic country where state life is based on the aspirations of its own people. The existence of public events that serve the state with all forms of support has an impact on the state, as the state must offer its citizens protection, rights and guarantees in order to continue to lead a dignified life and the public for their responsibility as a good society . In this process, the government must provide evidence to the public administration that the state can provide a forum for the community to continue to participate and take action based on transparency and accountability to create an efficient and fair environment for the community to create community. The form of participation that the municipality is responsible for is paying taxes. 
The tax awareness of the population can still be described as low, because there are still many people who are indifferent to paying taxes to the state. Tax negligence is also typically associated with multiple factors, such as a downturn in the economy leading to bankruptcy of large and small business owners.

The decline in economic stability is weakening other livelihoods in the country. In order to revive the country's economic life and rebuild the country's life on various foundations, Indonesia has implemented a system of good governance. Good governance is the quality of the relationship between government and the people it serves and protects [9]. According to the World Bank, good governance is the way in which the government contributes to the development of society with its power to manage human, social and economic resources [11]. The aim of good governance is to invite the community to participate in building the life of the country so that the economic life of a country can recovers in a recession, in accordance with the existing mutual relations between the community and the state itself.

There are several principles to be followed in developing good government in Indonesia. The principles of good governance are outlined by Manan [18], namely: accountable, accountable, controlled, transparent, limited and others. Meanwhile, UNDP in Kreen [19] promotes the following principles of good governance: participation, rule of law, transparency, responsiveness, consensus orientation, equity, efficiency and effectiveness, accountability and strategic vision. The very definition and principles of good governance show that good governance can be applied in a country's economic life. The application form for good governance in Indonesia is done by filing the tax policy. Taxes are the responsibility of the community, but the community itself often ignores them. Negligence on the tax itself causes undue harm to the community itself. One of these is that late payment of the tax leads to increased penalties for the tax itself.

The state, as the organizer of taxation, understands that the negligence of the population is an obstacle to the state's economy, while taxes are the greatest source of income that can contribute to the development and economic growth of the country. Thus, in accordance with the principles of good governance, the Indonesian government began to apply them in the life of the state and asked the public to cooperate in the return of the mandatory public funds. Proof that the state exercises good governance before society is the existence of a tax amnesty policy. This policy gives taxpayers who are in arrears for a limited time the option to pay a specified amount of tax and within a specified time in the form of an amnesty for tax debts in terms of both interest and penalties related to the previous tax period, or for a certain period of time without criminal punishment [2].

The existence of a tax amnesty policy is intended to relieve the situation of the debtors so that they can cooperate with the state in the development and growth of the country. The tax amnesty policy is respected by taxpayers under Section 3 of Chapter 3 of the Tax Amnesty Act, which states that all taxpayers can adhere to the tax amnesty policy if the taxpayer has a declaration letter disclosing their property. Legal entities are natural or individual taxpayers, but not yet taxpayers, corporate taxpayers, taxpayers in the micro, small and medium-sized enterprises (MSMEs) sector.

Considering the government's success in surpassing the Rs 4,000 trillion tax amnesty, repatriation of Rs 1,000 trillion and ransom demands of Rs. On the other hand, repatriation and ransom did not reach the goal. However, in terms of the successful declaration and denial of the Rs 135 trillion ransom, Indonesia has the highest revenue of any other country enforcing tax amnesty policy. In fact, the principle of good governance, which provides a tax amnesty policy, is a steppingstone for Indonesia that this policy can help APBN to be sustainable and have a good effect on the country because the state raises public awareness for taxpayers. 


\section{Conclusion}

From the above results and discussions, it is shown that the principle of good governance, supported by the government through the adoption of a tax amnesty policy, can raise public awareness of taxpayers. In addition, it has been proven that the community and the state can forge good cooperation and develop principles of good governance. Good governance with a tax amnesty policy reflects democratic public life and guarantees social justice for the entire Indonesian people and guarantees legal security.

\section{References}

[1] Agung, M.: Theory and Application of Indonesian Taxation. Jakarta: Publishing Dynamics of Science (2007)

[2] Ragimun.: An analysis of the implementation of the tax amnesty in Indonesia. Jakarta: Research and Development by the Fiscal Policy Agency of the Ministry of Finance of the Republic of Indonesia (2012)

[3] Yustiari, S.: Tax amnesty in terms of good governance. Scientific Journal for Public Administration (JIAP) 2 (4) (2016)

[4] Ispriarso, B.: The Success of Tax Amnesty Policy in Indonesia. Journal of Administrative Law and Management 2 (1) (2019)

[5] Uchitelle, E.: Effectiveness of the tax amnesty program in selected countries. Federal Reserve Bank of New York, Quarterly Review/Autumn, pp. 48-53 (1989)

[6] Safrijal, Basyah, M., Ali, H.: Application of the principles of good governance in the public service in the district of North Klute (2016).

[7] United Nations Development Program.: Local Co-Governance, Local Urban Initiatives Fund, Office for Development and Public Administration. New York, UNDP (1997)

[8] Slegman R. A. Edwin.: Essays on Taxation. New York (1925)

[9] Duarmas, D., Rumapea, P., Rompas, W.: Principles of good governance in the public service in the subdistrict of Cormolin, reign of West-Southeast Maluku. Journal of Public Administration 1 (37) (2016)

[10] Byrne, E., Arnold, AK, and Nagano, F.: Building Public Support for Anti-Corruption Efforts. Washington, DC: World Bank Governance and Accountability Program (2010)

[11] Adisasmita.: Local government administration. Yogyakarta: Graha Ilmu (2006).

[12] Wiriaatmaja, R.: Legal aspects of the supervision of state-owned companies that sell their shares on the capital market (advertising) to support the national economy. Dissertation, Postgraduate Program at Pajadjaran University. Bandung (2004)

[13] [13] Falakah, M.: Strategy for Clean and Good Government. Legal Solutions Bulletin (2007)

[14] Sugiarti, A.: Application of Good Governance Principles in the Management of Islamic Educational Institutions in SMA Muhammadiyah 3 Surabaya. Dissertation: State Islamic Institute Sunan Ampel Surabaya, Faculty Tarbia, Department of Islamic Education (2011)

[15] Sugiyono .: Quantitative, Qualitative, and Research Methods. Bandung: The Alphabet (2012)

[16] Muleong, L.: Qualitative research methods. Bandung: Youth Rosda-karya (2002)

[17] Moleong, L.: Qualitative research methodology. Bandung: PT. Rosdakarya Youth (2006)

[18] Manan, B.: Good governance prevents people from doing harmful governmental acts. Transparency Indonesia Issue 14 (1999)

[19] Krina, L.: Indicators and Measuring Instruments Principles of Accountability, Transparency and Participation, Secretariat for Good Governance. Jakarta: Bappenas (2003) 